FROM ASSYRIA TO ROME

Gojko Barjamovic - 9789004206236

Downloaded from Brill.com๑4/26/2023 07:55:15AM

via free access 


\title{
PRIDE, POMP AND CIRCUMSTANCE: PALACE, COURT AND HOUSEHOLD IN ASSYRIA 879-612 BCE ${ }^{1}$
}

\author{
Gojko Barjamovic
}

An essential component in understanding the structure and organisation of the Assyrian imperial court is its physical manifestation. The court as a social institution was set in the spatial framework of the royal palace. This was the setting in which the king and the imperial elite would interact, and a focal point of the imperial bureaucracy. It was a venue for the advertisement and manifestation of royal power and ideology, and a conspicuous backdrop for military reviews, political negotiations and the reception of foreign dignitaries. Finally, it was the home of the royal family. The present enquiry integrates the extensive written record of the activities of the Assyrian royal court with the material evidence obtained in excavations of the imperial state capitals and link the physical environment of the royal court to elements of function and conduct.

\section{The North-West Palace at Nimrud}

Perhaps the most important and best known example of an Assyrian royal residence is the so-called North-West Palace at Nimrud (Fig. 1). The building was constructed by Assurnasirpal II as the centre of a new state capital, when power was transferred from its ancient seat in the city of Assur during the first territorial wave of Neo-Assyrian expansion in the early ninth century B.C. A new and experimental layout and program of decoration was made to reflect the confident self-perception of the budding empire, and the new design involved a reinterpretation of the traditional functions of a royal palace. In time, the North-West palace came to be the essential architectural blueprint that was copied and developed in all later royal residences. The

${ }^{1}$ While writing this article, my close friend and colleague Stine Rossel lost her life in a tragic accident. I dedicate it to the lasting memory of her extraordinary personality and her treasured friendship. 


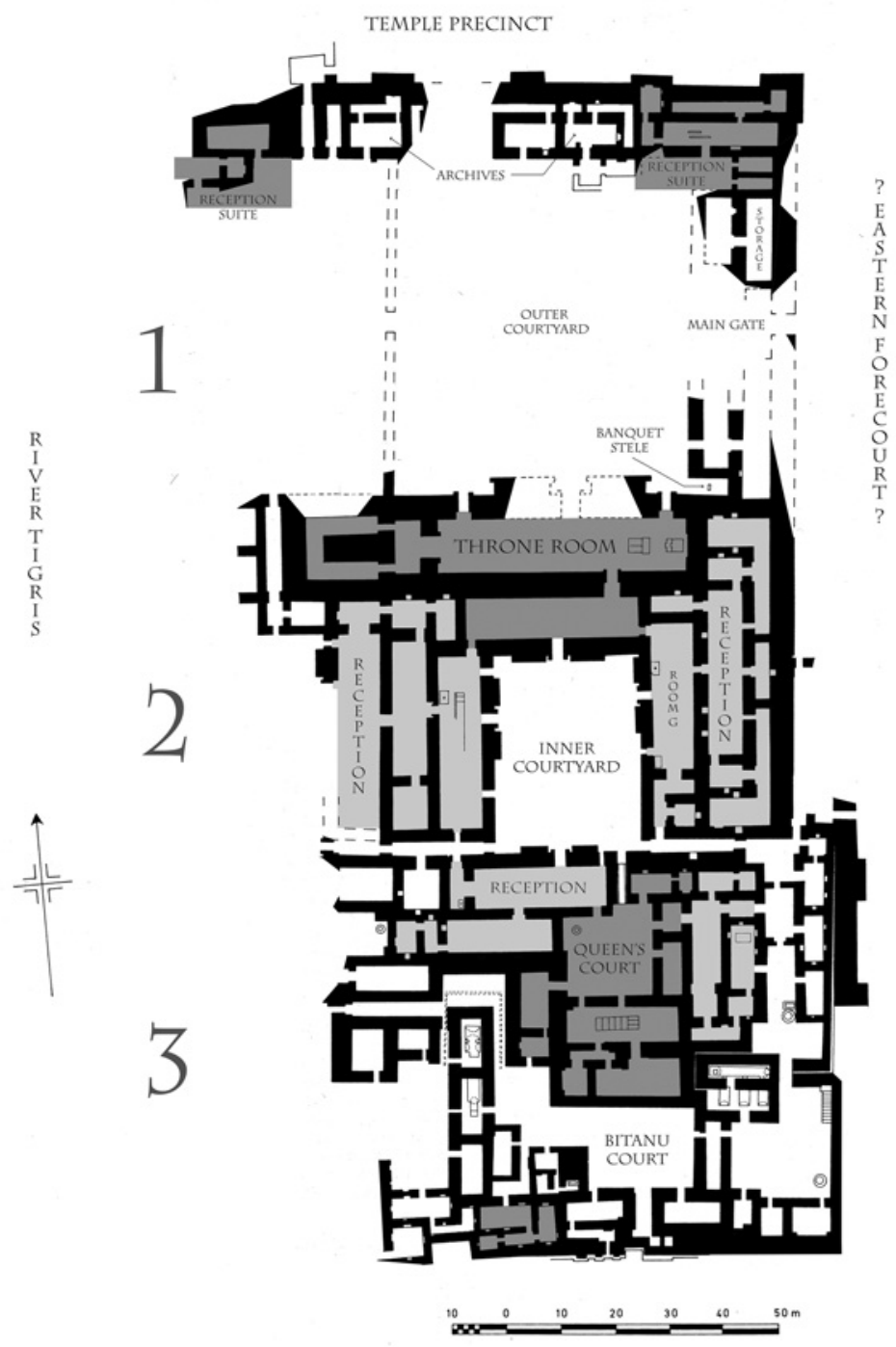

Figure 1. Plan of the North-West Palace. The three main sections of the palace have been numbered 1-3. Apparent reception areas, suites, the queen's court and a number of larger apartments in the living quarters of the palace have been highlighted in various shades of grey. 
structure itself continued to operate as a seat of the imperial family for more than two centuries, and even when the political capital moved to Dur-Sharrukin in the late 8th century and Nineveh in the early 7 th, some parts of the edifice continued to function as a seat for state activities and local provincial administration.

Although the western section of the palace has largely disappeared due to erosion, the excavated part of the building still covers an impressive area of more than $28,000 \mathrm{~m}^{2}$. This makes the structure fairly small in relation to the later Assyrian royal residences, but a comparison with the $13,000 \mathrm{~m}^{2}$ of the palace of Augustus in Rome plainly marks it as a momentous architectural, economic and artistic undertaking for its time. ${ }^{2}$ In some sections the North-West Palace would have risen to several stories, and roof space, terraces and porticos may also have played an important role in the function of the building. Unfortunately, the state of preservation and the early date of excavation of the main part of the building means that such information is now mostly lost to us. ${ }^{3}$

The North-West Palace is a particularly suitable starting point for a study of the physical setting of the Assyrian court for several reasons. A large part of its ground plan is available for study, the building represents an early prototype of a Neo-Assyrian palace, and a large and well-recorded assemblage of archaeological artefacts helps to identify the activities that took place in the structure as well as the identity of those who performed them. Also, the architectural layout shows a strong intentionality and sense of rationale, and the individual elements of the building reflect and serve a closely defined set of functions

${ }^{2}$ For the palace of Augustus see Inge Nielsen, Hellenistic Palaces. Tradition and Renewal, Studies in Hellenistic Civilization 5 (Århus 1994) pp. 173 ff. For a general overview of palaces in the ancient Near East, see Irene J. Winter, "Seat of Kingship"/“A Wonder to Behold": The Palace as Construct in the Ancient Near East', Ars Orientalis 23 (1993) pp. 27-55.

${ }^{3}$ For the early excavations, the rediscovery of Assyria in European scholarship, and its close ideological bonds with French, German and British imperialism, see Mogens T. Larsen, The Conquest of Assyria: Excavation in an Antique Land, 1840-1860 (New York; London 1996) and Suzanne Marchand, 'Orientalism as Kulturpolitik: German Archeology and Cultural Imperialism in Asia Minor', in: Volksgeist as Method and Ethic: Essays on Boasian Ethnography and the German Anthropological Tradition, George W. Stocking, Jr., ed., History of Anthropology 8 (Madison 1996) pp. 298-336. The history of excavations at Nimrud has been summarised in Joan and David Oates, Nimrud: an Assyrian Imperial City Revisited (London 2001). 
associated with the new regime. ${ }^{4}$ Even to a modern audience its decoration helps to expose a distinct set of meanings.

The spatial organisation of the building seems to follow a fairly straightforward design, each sector relating to a number of large courtyards and key rooms with a specific purpose. ${ }^{5}$ The main gate in the monumental façade on the eastern side of the palace gave access to a large outer courtyard and a number of surrounding rooms that together constituted the precinct occasionally referred to in the Assyrian texts as the 'gate' or 'outer' wing ( $b \bar{a} b \bar{a} n u)$ of the building. ${ }^{6}$ A small entrance in the northern wall of the courtyard connected a series of

${ }_{4}$ The main analysis is found in John Malcolm Russell, 'The Program of the Palace of Assurnasirpal II at Nimrud: Issues in the Research and Presentation of Assyrian Art', American Journal of Archaeology 102, 4 (1998) pp. 655-715, with particular reference to the work of Amos Rapoport, 'Systems of Activities and Systems of Settings', in: Domestic Architecture and the Use of Space. An Interdisciplinary Cross-Cultural Study, Susan Kent, ed., New Directions in Archaeology Series (New York 1990) pp. 9-20, in relation to the phenomenon of redundancy of cues in architecture.

${ }^{5}$ A number of dedicational inscriptions related to the foundation of the palace were physically incorporated in the building, showing that the Assyrian builders themselves distinguished the different wings of the palace by the use of a particular type of exotic wood in its decoration: "I cleared away the old ruin hill (and) dug down to the water level. I sank (the foundation pit) down to a depth of 120 layers of brick. I founded therein a palace of cedar, cypress, daprānu-juniper, boxwood, meskannuwood, terebinth and tamarisk as my royal residence (and) for my lordly leisure for eternity. I made beasts of mountains and seas in white limestone and parütu-alabaster (and) stationed (them) at its doors. I decorated it in a splendid fashion; I surrounded it with knobbed nails of bronze. I hung doors of cedar, cypress, daprānu-juniper (and) meskannu-wood in its doorways", Albert K. Grayson, Assyrian Rulers of the Early First Millennium BC I (1114-859 BC), The Royal Inscriptions of Mesopotamia, Assyrian Periods, vol. 2 (Toronto 1991) A.0.121.2, pp. 52-60. Hundreds of similar dedicatory inscriptions by Assurnasirpal II have been uncovered in the North-West Palace. All are edited and translated in Grayson, Assyrian Rulers. Unfortunately, the general state in which the building is preserved prevents one from tracing this ancient partition, and instead one is compelled to consider physical access, room decoration and the artefacts recovered from the building to divide the structure into meaningful functional units. One exception is the treasury just south of the western banquet suite (vide infra), where the later Assyrian ruler Sargon II left an inscription stating that he had restored the juniper-wing of the palace. Interestingly, the feature we tend to focus upon as most characteristic element of an Assyrian palace today, namely the kilometre-long rows of stone-cut panels decorated with brightly painted reliefs, receives no mention in the ancient account.

${ }^{6}$ See Oates, Nimrud, for the detailed study of the architecture and finds from the North-West Palace. The area east of the main gate has never been properly investigated, and it is entirely possible that an additional outer court would have given access to the ba $\bar{a} \bar{a} n u$ in the manner of the later Assyrian palaces at Khorsabad and Nineveh, see Julian E. Reade, 'The Ziggurat and the temples of Nimrud', Iraq. Journal of the British School of Archaeology in Iraq 64 (2002) pp. 135-216. The apparent lack of any quarters for the royal guard would seem to support this conclusion. 
storerooms and archives to the temple precinct and the ziggurat-tower beyond the palace enclosure. ${ }^{7}$ In addition, a minor gate in the western wall would presumably have led down to the Tigris quay adjacent to the citadel walls, but all remains of such a structure have been obliterated by erosion.

The $b \bar{a} b \bar{a} n u$ consisted of two parts, each tied to a similar set of apartments belonging to officials of sufficient importance to be treated with considerable ceremony. Both apartments consisted of an antechamber, a reception area, rooms for ablutions, storage facilities, and presumably also an upper structure with living quarters for the official. The remaining rooms surrounding the courtyard were laid out to store bulky commodities such as wine, grain and oil, and scribal offices were located in the immediate vicinity of the service entrance to the north. When excavated, the archives still contained filing cabinets with documents found in situ and included a large number of important state letters and official correspondence. ${ }^{8}$ Other records refer to the storage of oil, wine and large amounts of grain (a single text mentions some three million litres). One also finds physical evidence for domestic activities in the bābannu precinct, such as carbonised wheat, barley and linseed, mortars, grindstones, spindle whorls and loom weights. ${ }^{9}$ Three large gates flanked by giant statuary lead from the southern façade of the main courtyards into the central part of the palace and the throne-room suite of the king. The southern wall of the courtyard was decorated with reliefs showing a procession of foreign dignitaries carrying gifts and tribute in plain reference to the ceremonies that would have been conducted in the adjacent throne-room (Fig. 2). The physical layout of the outer courtyard precinct, the recovered artefacts, and the presence of administrative records from the palace chancery all point to the function of the bābannu as a centre of administration as well as domestic activities, and an initial reception area of visitors to the imperial court. ${ }^{10}$

\footnotetext{
${ }^{7}$ Reade, 'The Ziggurat' provides a comprehensive study of the temple precinct directly north and east of the North-West Palace.

${ }^{8}$ The state letters from Nimrud are published in Henry W.F. Saggs, The Nimrud Letters, Cuneiform Texts from Nimrud 5 (London 2001).

${ }^{9}$ Oates, Nimrud, pp. 42-47. For the skilled craftsmen (kurtaš) employed in the royal workshops at the later Persian palaces, see Pierre Briant, From Cyrus to Alexander. A History of the Persian Empire (Winona Lake 2002) p. 257.

${ }^{10}$ For the use of the terms bābānu and bitānu, see The Assyrian Dictionary of the Oriental Institute of the University of Chicago [CAD] (Chicago 1956-2010) vol B.,
} 


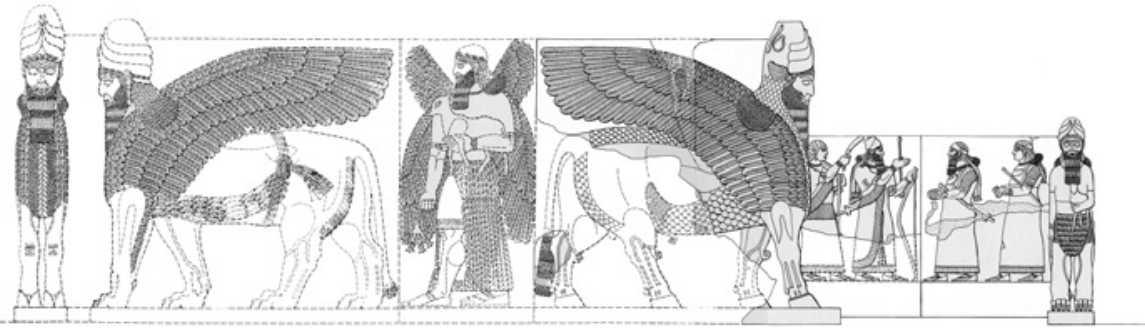

Figure 2. The relief decoration of the southern wall of the outer courtyard of the North-West Palace. The frieze continues from p. 32 onto p. 33. To the right foreign dignitaries are shown entering the doors to the throne room behind the wall carrying valuable gifts. To the left the king and the crown prince receive foreign embassies led to them by Assyrian

The grand throne-room behind the southern façade of the outer courtyard marks the nexus of the palatial complex. Its walls were covered in almost 3-m-high stone slabs carved in low relief and painted in bright contrasting colours of red, black and blue. In addition, each slab bears a long commemorative text relating the royal titles and achievements of Assurnasirpal written in the high literary dialect of the Babylonian language. The plastered walls and doorways were painted or decorated with delicate bands of glazed brick. Thick rugs similar to the later well-known Persian designs covered the floor of the room, and the tall doors were embellished with intricately sculpted bronze bands. The royal throne stood on a raised podium at the eastern end of the room.

The carved scenes on the walls show pitched battles, the siege of a walled city, open cavalry encounters, and the capture of an island fortress (Fig. 3). Both the visual impact and the authenticity of the narrative are striking and mark the first clear Assyrian attempt at producing historical narrative on a monumental scale for an audience that may have been predominantly illiterate. The geographical extent of the empire is represented by the placement of particular scenes within the composition, ${ }^{11}$ and each episode refers to specific incidents and indi-

pp. 7, 274-275. At the Achaemenid court the expression 'those of the gate' became a common term for the palace functionaries in general, see Briant, From Cyrus to Alexander, p. 260.

${ }^{11}$ An extensive literature on the subject of the Neo-Assyrian palace reliefs has appeared in the past three decades. Most important for the palace of Assurnasirpal II are: Julian E. Reade, 'Narrative Composition in Assyrian Sculpture', Baghdader 


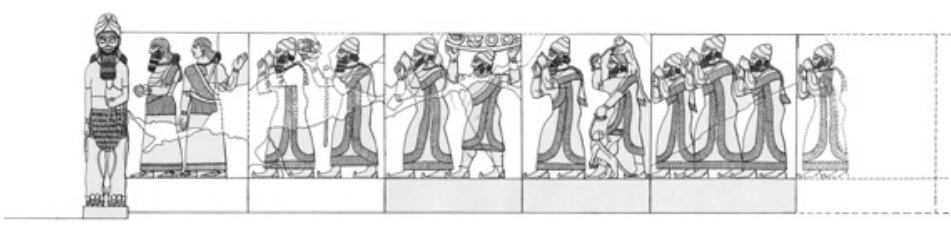

eunuchs and bearded courtiers. Some foreigners bring valuables and exotica while others present the golden torcs they presumably just received as audience gifts from the Assyrian ruler. Winged bulls and protective spirits guard the grand central gate. Reproduced from Paley and Sobolewski 1992, pl. 4.

viduals that would have been familiar to the contemporary audience: the fortress in the island was in fact taken, and the besieged city did fall to the Assyrian army led by its king and crown prince. In a sense therefore, the actions portrayed are historically correct, although they are of course far from realistic. The art could only handle victories, and natural and human-made obstacles are shown only as a preamble to the Assyrian king and his army overcoming them. The role of the Assyrian king as a universal ruler is emphasised throughout the imagery, and his military, religious and political power is underlined by juxtaposition to the generic lines of vanquished enemies-corpses and prisoners of war being led from conquered cities and battlefields. The atmosphere is one of invincible power and "calculated frightfulness", ${ }^{12}$

Mitteilungen 10 (1979) pp. 52-110; idem, 'Texts and Sculptures from the North-West Palace, Nimrud', Iraq. Journal of the British School of Archaeology in Iraq 39 (1985) pp. 203-214; Russell, 'The Program of the Palace of Assurnasirpal II'; idem, The Writing on the Wall: Studies in the Architectural Context of Late Assyrian Palace Inscriptions (Winona Lake 1999), and Irene J. Winter, 'Royal Rhetoric and the Development of Historical Narrative in Neo-Assyrian Reliefs', Studies in Visual Communication 7, 2 (1981) pp. 2-38; eadem, 'The Program of the Throneroom of Ashurnasirpal II', in: Essays on Near Eastern Art and Archaeology in Honour of Charles Kyrle Wilkinson, Prudence O. Harper and Holly Pittman, eds. (New York 1983) pp. 15-31; and eadem, 'Art in Empire: The Royal Image and the Visual Dimensions of Assyrian Ideology', in: Assyria 1995-proceedings of the 10th Anniversary Symposium of the Neo-Assyrian Text Corpus Project, Helsinki, September 7-11, 1995, S. Parpola and R. Whiting, eds. (Helsinki 1997) pp. 359-381. Recent treatments of the approach to pictorial narrative in the North-West Palace are found in S. P. Lumsden, 'Narrative Art and Empire: The Throneroom of Aššurnașirpal II', in: Assyria and Beyond. Studies Presented to Mogens Trolle Larsen, Jan Gerrit Dercksen, ed., Publications de l'Institut historiquearchéologique néerlandais de Stanboul 100 (Leiden 2004) pp. 359-385; Mehmet Ali Ataç, 'Visual Formula and Meaning in Neo-Assyrian Relief Sculpture', The Art Bulletin 88, 1 (2006) pp. 69-101, and Zainab Bahrani, Rituals of War. The Body and Violence in Mesopotamia (New York 2008).

${ }_{12}$ Albert T. Olmstead, 'The Calculated Frightfulness of Ashur Nasir Apal', Journal of the American Oriental Society 38 (1918) pp. 209-263. 

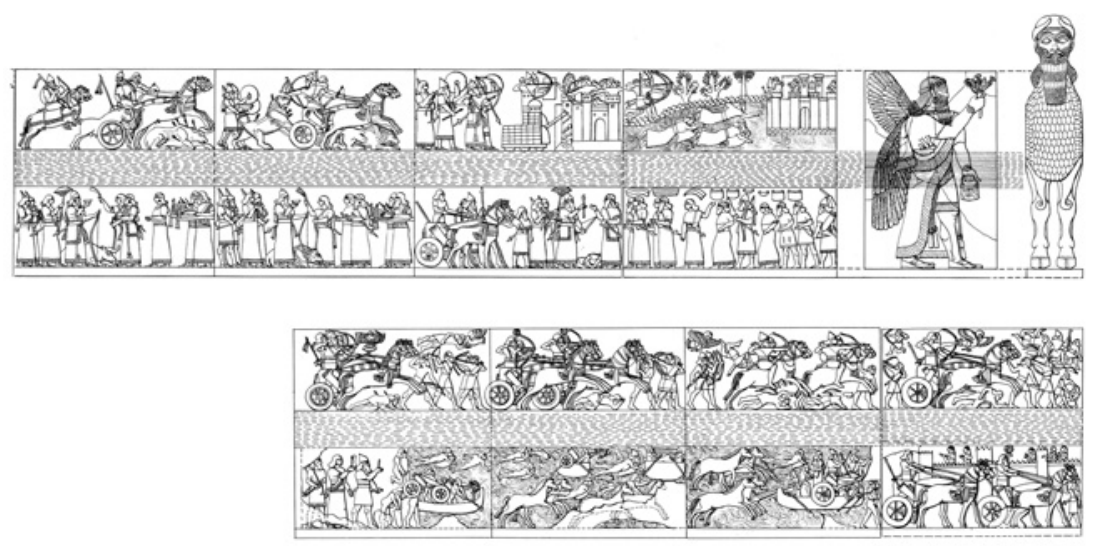

Figure 3. The relief decoration on the southern wall of Assurnasirpal II's throne-room of the North-West Palace. The illustration represents a continuous decorative band measuring $45.7 \mathrm{~m}$ that has been broken up into four parts in order to fit it onto two pages. It runs from the upper register of p. 34 onto p. 35 and it continues in the lower register on p. 34 from left to right. On the upper left, and next to where the royal throne would have stood, the reliefs show hunting scenes. The remaining scenes show open battles, siege, Assyrian forces and prisoners of war. The central

and the visual syntax underlines the intimate relation between the Assyrian king and divine Aššur as opposed to the heretical behaviour of his defeated foes.

A doorway set in the western end of the throne-room gave access to a grand staircase that presumably led to a second story or roof terrace where the ruler would stand to greet passing processions of dignitaries at grand imperial celebrations. ${ }^{13}$ Beyond an antechamber a large courtyard led to three distinct suites of reception rooms, shown in different shades of grey on the plan below. The western suite was accessible from the bābannu either directly through the throne-room or via a corridor leading to a porch overlooking the river. Judging by later architectural parallels at Khorsabad and Nineveh, the purpose of these rooms was to receive royal guests in a stately manner for banquets and

${ }_{13}$ Note e.g. the reference in the letter in Steven William Cole and Peter Machinist, Letters from Priests to the Kings Esarhaddon and Assurbanipal, SAA 13 (Helsinki 1998) no. 80: "The face of the king, my lord, has been seen by very many people. Let an order be given to the palace supervisors: when the elders pass beneath the terrace, let them allow me to see the face of the king, my lord, and may the king look at me." 

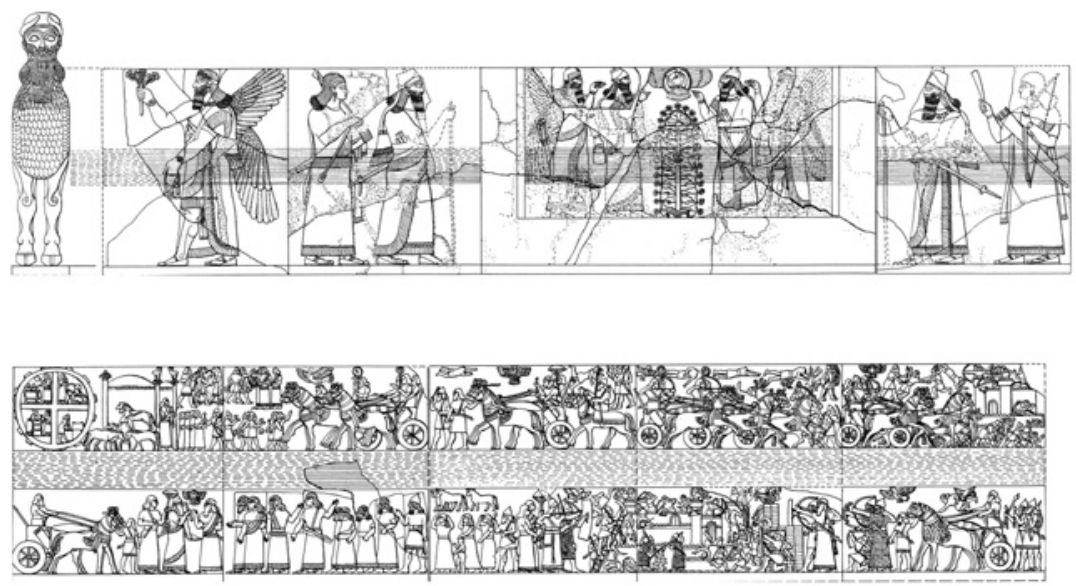

scene, which is set in a raised panel directly across from the grand entrance opening onto the outer courtyard, shows the king and winged genies flanking an image of the sacred tree. Reproduced from Meuszynski 1981, pl. 1-2.

entertainment. ${ }^{14}$ Wall reliefs illustrate such banquets and show seated guests on elaborate furniture consuming exquisite food and drink while attended by servants, singers and musicians (Fig. 4). ${ }^{15}$

The smaller rooms in the suite would have included storage facilities for fittings, dishes etc., and the so-called 'ablution-rooms' that may have functioned as toilets and baths. ${ }^{16}$ South of the banquet-suite a number of small, disconnected rooms may have formed the palace treasury. In a commemorative inscription found in situ, the Assyrian ruler Sargon II celebrates the repair of this section of the palace, stating that he had $345 \mathrm{~kg}$ of gold and $63,012 \mathrm{~kg}$ of silver stored in it. ${ }^{17}$ Likewise, in the

${ }^{14}$ See Geoffrey Turner, 'The State Apartments of Late Assyrian Palaces', Iraq. Journal of the British School of Archaeology in Iraq 39 (1970) pp. 177-213, and the comprehensive analysis in Russel, "The Program of the Palace of Assurnasirpal II at Nimrud'.

${ }^{15}$ For the records of various royal banquets, listing items on the menu and people attending, see Frederico Mario Fales and J. Nicholas Postgate, Imperial Administrative Records. Part I. Palace and Temple Administration, SAA 7 (Helsinki 1992) nos. 148-157; for lists of the aromatics, fumigants and sweets consumed at such occasions, see nos. 145-147.

${ }^{16}$ Compare e.g. to the baths found at Persepolis. Several written references show that the Persian king (Aelian, VH XII.1) and his nobles (Polyaenus VIII.16.1; Diodorus XIV.80.8) would retire here to bathe and relax on a regular basis.

17 Daniel David Luckenbill, Ancient Records of Assyria and Babylonia (Chicago 1927) vol. 2, pp. 72-73. 

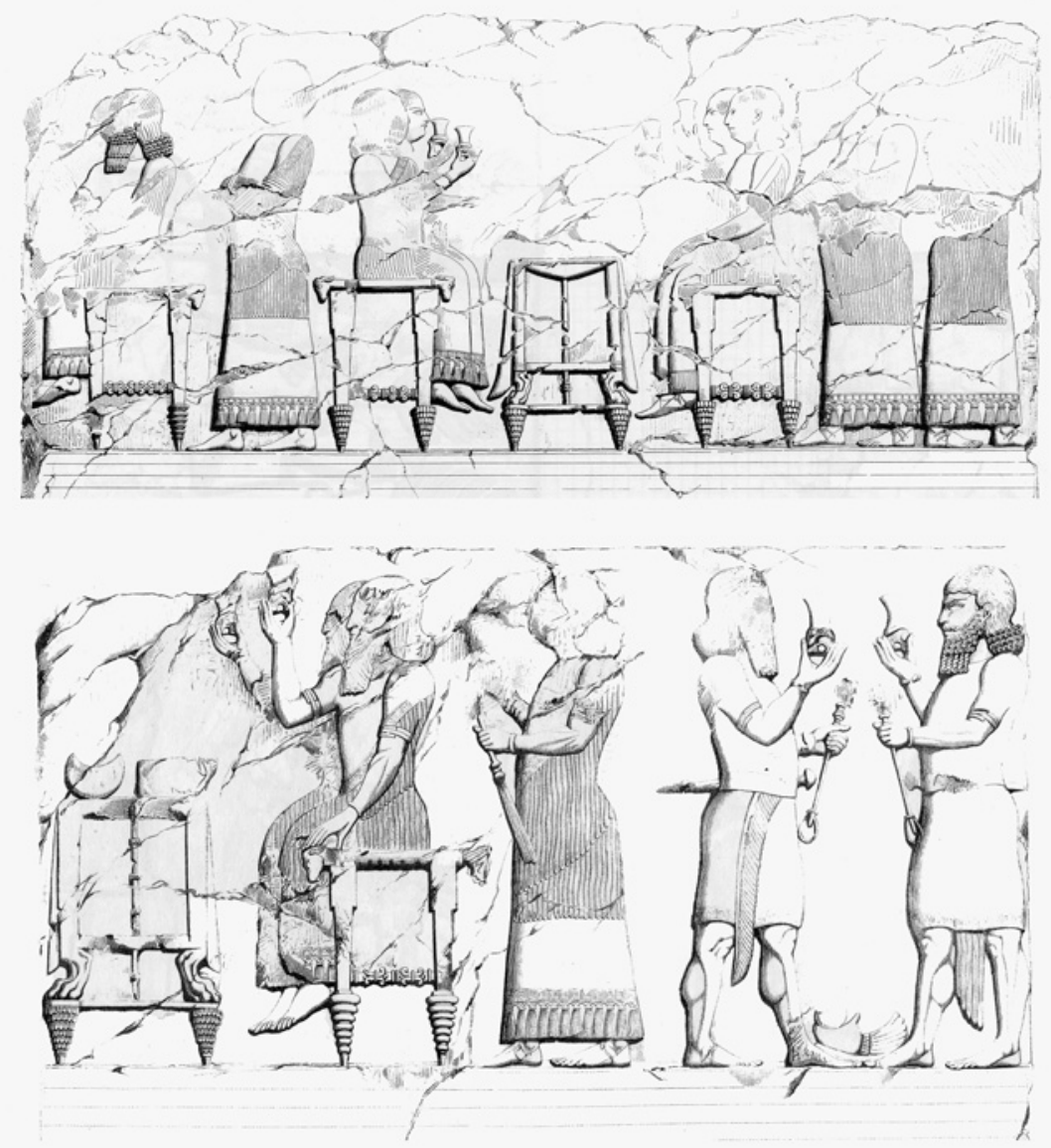

Figure 4. Reliefs showing banquet scenes. From rooms 2 and 7 in Sargon II's palace at Khorsabad (ancient Dür Šarrukinn). Eunuchs and bearded courtiers, some of them with sceptres, are shown standing or seated on elaborate chairs while eating and drinking wine served from large cauldrons in rythons. Line drawings by E. Flandin reproduced from Botta 1846-50 vol. i pl. 65 and vol. ii pl. 112. 


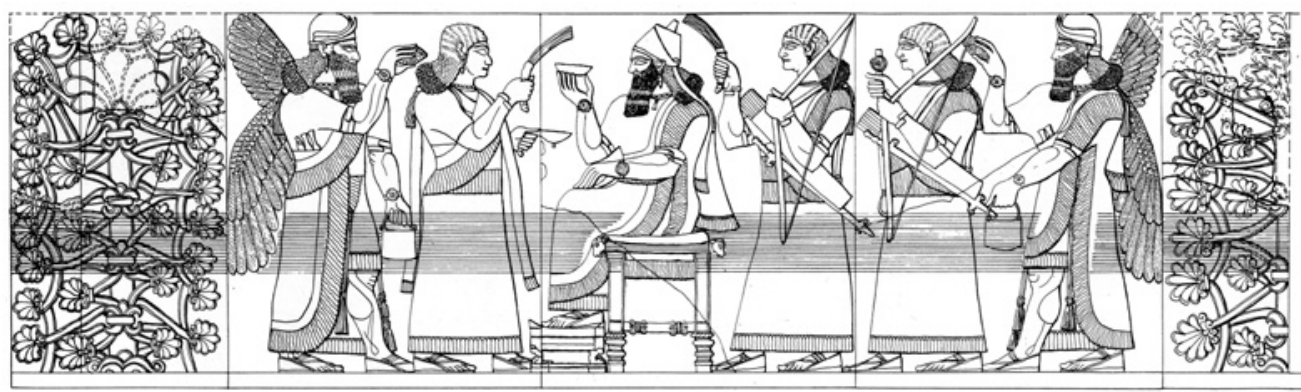

Figure 5. Relief from the North-West Palace room G of the eastern reception suite. The panels show the king drinking wine surrounded by eunuchs and protected by bearded genies and the sacred tree. Reproduced from Meuszynski 1981 plate 8.

nearby room a deep well was found to contain hundreds of fragments of fine ivory furniture and decorative pieces, presumably belonging to objects that had been kept in the nearby treasuries but were torn apart and discarded during the final sack of the palace in 612 B.C. ${ }^{18}$ On the eastern side of the courtyard was a second suite of reception rooms. ${ }^{19}$ Reliefs showing the king seated on his throne in splendid robes and drinking wine in the company of his officers, genii and images of the sacred tree may indicate its use as a setting for royal symposia (Fig. 5). ${ }^{20} \mathrm{~A}$ final third group of rooms, just south of the inner courtyard, is decorated with reliefs showing winged genii attending the sacred tree. The composition focuses on an image of the king in warlike attire flanked by armed courtiers.

${ }^{18}$ Oates, Nimrud, pp. 90ff.

19 For a different opinion on the use of these rooms, cf. e.g. Russell, 'The Program of the Palace of Assurnasirpal II', pp. 671-673.

${ }^{20}$ The importance of the royal symposia can not be gleaned directly from the textual evidence, but the large amounts of wine distributed to the officials of the palace, the rich pictorial evidence for symposia on palace reliefs, and the finds of numerous implements associated with wine drinking in the Assyrian royal palaces add to the vivid narratives from the Persian court about the delicate ceremonial surrounding such occasions. In Persepolis, the Royal Cupbearer alone had the task of tasting and delicately pouring the wine for the king, thereupon presenting: "the goblet conveying it with three fingers, to offer it in such a way as to place it most conveniently in the grasp of the one who is to drink" (Xenophon, Cyr. I.3.8), see also Briant, From Cyrus to Alexander, p. 264. Surely the Assyrian Chief Cupbearer ( $r a b$ šäqê) portrayed on the Khorsabad reliefs had similar, if not identical, responsibilities. For the amounts of wine distributed to the officials of the palace, see J.V. Kinnier Wilson, The Nimrud Wine Lists, Cuneiform Texts from Nimrud 1 (London 1972). 
Based upon the ground plan and room decoration one may speculate about the exact functional differences between the three reception suites, but a general interpretation of the central section of the palace as a functional extension of the throne-room to receive guests in more private surroundings seems probable. Plainly, the throne-room, the treasury and the state apartments were the locus of power par excellence in the empire. It was where the king presided, where strategic decisions were made, and where the imperial magnates, advisors and foreign ambassadors were summoned for political, religious and social functions.

The southernmost extension of the palace consisted of the private living quarters of the royal family and their closest servants. In the contemporary sources occasional references to the bìtānu ('interior' or 'domestic') wing distinguish it from the bābānu ('outer' or 'official') section. Secluded from the outside world and accessible only through a fairly limited number of access points, it housed the palace women, their children, their ladies in waiting and the household staff. A number of small courtyards lead to separate sets of domestic chambers, each with fairly restricted linear access. Rooms, sometimes equipped with built-in cupboards, water-storage and adjacent bathrooms, each form a unit suitable for living quarters or administrative offices for individuals or small groups. Below the floors lay the tombs of the predominantly female occupants of the wing.

Finds from the bitānu include precious objects that can easily be associated with life in the private sector of the palace. One room was found to contain religious and lexical texts that may have belonged to a small palace library, and some chambers housed the archives of palace functionaries operating from the domestic wing. ${ }^{21}$ Occasional references in the records to the procurement of wool and livestock for the residents of the palace adds to the image of the building as a space

${ }^{21}$ Olof Pedersén, Archives and Libraries in the Ancient Near East, 1500-300 BC. (Bethesda 1998), pp. 147-151. The religious and lexical texts are published in J. Nicholas Postgate, The Governor's Palace Archive, Cuneiform Texts from Nimrud 2 (London 1973), nos. 268-272, and the administrative texts and dockets as nos. 247-265. Part of an archive was unearthed in the connecting hall west of the bitannu-court. Selected texts have appeared in Karlheinz Deller and Abdulillah Fadhil, 'Neue Nimrud-Urkunden des 8. Jahrhunderts v. Chr.', Baghdader Mitteilungen 24 (1993) pp. 243-270, and in Ali Y. Ahmad and J. Nicholas Postgate, Archives from the Domestic Wing of the NorthWest Palace at Kalhu/Nimrud, Edubba 10 (London 2007). 
for work as well as living. ${ }^{22}$ At least two wells supplied its residents with water.

A prominent court and a suite of rooms just south of the inner courtyard appear to form a larger official apartment that presumably represents the court of the Assyrian queen. She is known to have been the head of a separate household with a distinct hierarchy of administrative as well as military officials. Fragments of ivory furniture, lavish murals, glazed wall knobs for hanging tapestries, and large amounts of gold sheet were recovered from these rooms, underlining the comparative wealth and importance of its occupant. In the Greek sources, the bedchamber of the Persian king is a recurring topos in the court narratives, but next to nothing is known about the private quarters of the Assyrian ruler and his queen. Perhaps they were located on an upper floor of the building and left no discernable trace. Only a single staircase has been identified in the bitannu, but the width of the walls in the western section of the complex seems to indicate that substantial chambers could have been located on the first floor of the building, overlooking the Tigris. If the association of the nearby suite with the Assyrian queen is correct, her upper apartments would have been immediately adjacent to the king's bedchamber.

\section{Visitors and Protocol in the Assyrian Imperial Household}

The detailed archaeological record of the physical setting of the Assyrian royal court may be connected to an extensive number of written sources to help form a comprehensive image of the social hierarchy and state protocol in relation to its spatial component. Owing to the fact that the palace administration wrote its records on clay tablets, which survive very well in the archaeological record, a unique range of documents has come down to us from the everyday management of the building. In addition to state treaties, judicial records, omens, royal annals and a substantial political correspondence, a large number of administrative accounts give valuable information about the demography of the imperial household. Conversely, the type of detailed narratives set at the Persian court that one finds in the classical Greek

${ }^{22}$ Several texts list palace women and their weavers, and a docket found in the domestic wing records the substantial delivery of more than a ton of wool and almost $200 \mathrm{~kg}$ of goat's hair, cf. Postgate, The Governor's Palace Archive, no. 254. 
literature are lacking entirely from the Assyrian record. The present study therefore gains additional information through extrapolation and cross-reference to accounts of the Achaemenid royal household, whose imperial symbolism, protocol and administrative template to a large part derive from its Assyrian predecessor.

An important key to understanding Assyrian court etiquette and social hierarchy is found in a codified manual of the procedures enacted at a royal banquet. This unique text gives a detailed impression of the highly controlled ceremony and protocol associated with such occasions, and provides us important hints about the status and function of the royal servants:

On the day of the banquet, when the king enters the feast together with the magnates, the table and the divan for the king are placed opposite the doorway. When the king is seated, the palace supervisor enters, kisses the ground in front of the king, and gives his report to the king. The palace supervisor goes out and leads in the palace herald. The palace herald enters, kisses the ground before the king, and takes up position before the king with the standard. The palace herald gives his report to the king. The palace supervisor goes out, and he leads in the grand vizier. The grand vizier enters, kisses the ground before the king at the threshold, and stands opposite the king. The palace herald and the grand vizier go out. ${ }^{23}$

The palace herald and the grand vizier rank among the most important officials in the Assyrian Empire, and both belonged to the group known as the 'magnates' (rabiu) who stood immediately below the king, the queen and the crown prince in the imperial hierarchy. In the present context, however, the palace supervisor ( $\check{s} a$ pann ekalli) clearly holds the role of introducer to the king and chief of palace protocol. Although his position in the overall state hierarchy was far below the herald and the grand vizier, and each royal palace in the empire had one or more palace supervisors, his position inside this narrow social framework evidently granted him an exceptional status. At the court of the Persian king, the official known in Greek as the chiliarch carried out similar functions, and his personal intercession was allegedly required for any visitor to be granted a royal audience. In fact, several classical authors count the chiliarch among the highest ranking bureaucrats at the Achaemenid court, even if the Persian evidence sug-

${ }^{23}$ Copy and edition in Karl F. Müller, Das assyrische Ritual I: Texte zum assyrischen Königsritual. Mitteilungen der vorderasiatisch-ägyptischen Gesellschaft 41/3 (Leipzig 1937). 
gests otherwise.$^{24}$ His function as introducer to the king as his subjects was obviously of paramount importance to visiting outsiders, and a Greek misconception about his relative status in the imperial hierarchy is easily explained.

That the Assyrian palace supervisor would have held similar powers in deciding who could enter the palace and meet the king may be gleaned from the following passage from a letter written by Assurbanipal in a reply to a complaint filed by the city assembly at Nippur:

And in regard to what you wrote: "When fifteen of our elders came to greet the king, only half of us were (allowed) to enter before the king"... This is the fault of the sandabakku, who is your governor, and secondly, of the palace supervisor, who did not admit you into my presence. By Aršsur, my God, I swear that I did not know that only half of your number had entered before me. How should I know who is who? ${ }^{25}$

The level of formalised communication at the royal audience is also evident from the apparent failure of the elders to simply inform the king about their absent colleagues, and one may speculate whether most meetings between the king and his subjects may have been stylised to a point where they involved little direct communication. The position of an official with 'gate-keeping' duties, who decided not only who was to be granted a royal audience, but also the topic and outline of that audience, is well-known from other courts and leads to obvious conjectures about the Assyrian palace supervisor. It would appear that he was among the few high officials actually resident at the royal palace itself, and in reference to the ground plan of the North-West Palace at Nimrud one may speculate whether the reception suite immediately north of the main gate could have belonged to his office. Here the supervisor would be able to receive visitors and grant them entry to the bābānu and the king.

There was no Assyrian nobility in the strict sense of an exclusive society of interrelated landed gentry and a formalized system of hereditary titles. Certainly, several of the king's magnates could produce impressive pedigrees, but the inclusive character of Assyrian imperialism encouraged the integration of foreign and local elites

\footnotetext{
${ }^{24}$ Briant, From Cyrus to Alexander, pp. 258-261.

${ }^{25}$ Cf. Robert F. Harper, Assyrian and Babylonian Letters belonging to the Kouyunjik Collection of the British Museum vols. I-XIV (Chicago 1892-1914) p. 287, and note also the letter in Cole and Machinist, Letters from Priests to the Kings, no. 80 quoted above.
} 
directly into the highest echelons of society. In addition, a large number of magnates were eunuchs, who at least nominally had their ties to family and outside loyalties severed by castration. Although there have been recent attempts to prove otherwise, it is difficult to demonstrate the existence of a royal council with permanent membership held by particular officials. ${ }^{26}$ Rather, it seems that individual merits, devotion and loyalty were decisive for the particular privileges and responsibilities bestowed upon each officer. Nevertheless, it seems clear that the highest offices of the Empire included at least seven specific officials referred to as 'the king's magnates', namely the treasurer (masennu), the palace herald (nägir ekalli), the chief cupbearer ( $r a b \check{s} \bar{a} q \hat{q})$, the chief eunuch ( $r a b \breve{s} a-r \bar{e} s i)$, the chief judge (sartinnu), the grand vizier (sukallu) and the commander-in-chief (turtānu). ${ }^{27}$

The majority of these offices came with large territorial provinces, and evidently the main executors of the Empire would have been absent from the central court for large parts of the year to manage their households in the provinces, to lead armies in military campaigns, and to perform political or ritual obligations on behalf of king and empire. Furthermore, it is clear that the attendance of these high officials at court did not necessitate their actual residence at the royal palace. Instead, most, if not all, of the magnates maintained extensive

${ }^{26}$ See Simo Parpola, 'The Assyrian Cabinet', in: Vom Alten Orient zum Alten Testament: Festschrift für Wolfram Freiherrn von Soden zum 85. Geburtstag am 19. Juni 1993, Manfried Dietrich and Oswald Loretz, eds. (Freudenstadt 1995) pp. 379-401, and Raji Mattila, The King's Magnates. A Study of the Highest Officials of the NeoAssyrian Empire, State Archives of Assyria Studies 11 (Helsinki 2000), and the critical review of Parpola's ideas in Jerrold Cooper, 'Assyrian Prophecies, the Assyrian Tree, and the Mesopotamian Origins of Jewish Monotheism, Greek Philosophy, Christian Theology, Gnosticism, and Much More', Journal of the American Oriental Society 120, 3 (2000) pp. 430-444.

${ }^{27}$ Importantly, this image is subject to chronological variation, and there is the real danger that undated texts, such as the banquet manual and the coronation ritual, reflect very different social circumstances, more than a century apart. Most of the offices are first attested during the reign of Assurnasirpal, and may constitute a part of the same overall reform instituted during his rule that also resulted in the moving of the state capital from Assur and the construction of the North-West Palace. However, the chief judge and the grand vizier are relative latecomers, and their offices seem to gain prominence only in the late 8th century. Similarly, the office of the commanderin-chief was divided in two (the commander-in-chief of the left and the commanderin-chief of the right) in 708 B. C., when also the palace herald and the chief cupbearer may have been demoted in the relative hierarchy of the king's magnates. In contrast, the governor of Damascus during this period seems to have held very close ties to the Assyrian king, and therefore to have held a particularly strong influence at the royal court. For a comprehensive analysis of the magnates, see Mattila, King's Magnates. 
households in the state capital as an addition to their provincial territory and prebendary lands spread throughout Assyria. The chief judge, the grand vizier and the chief eunuch seem to have had no province attached to their offices, and the latter is attested as the head of the permanent royal military corps (kișir šarri) and resident of a substantial court manor in the state capital.

Returning to the document describing the royal banquet, the text continues with the Crown Prince and the remaining royal sons and their entourage entering the room where the king is seated in waiting for the dinner. A detailed account is given of the procedures related to the servants attending censers used for burning aromatics and charcoal braziers. One royal lackey has to collect dirty napkins and hand out clean ones, while another is to pour the water used for washing hands. A servant keeps constant watch with a broom and a dustpan in case anything falls to the floor, while others see to the serving of the food and drink. When the sun is about to set, select servants hold torches between the tables of the 'magnates', while others keep watch over the torches and change them as they burn down. Officials of particular importance in relation to the feast are the chief eunuch ( $r a b$ $\check{s} a-r \bar{e} s i$ ) and the chief cook (rab nuhatimmi) but once again the palace supervisor stands in charge of protocol. When the dinner is ready to begin:

Grand goblets are set on the tables. The palace supervisor steps forward, saying: "Cupbearer, pour the drink!"... Then the chief cook announces: "Dinner is served." The Crown Prince begins (the feast). (After the dinner) the 'great men' rise and remain standing. The tables of the Crown Prince and the 'magnates' are lifted up. The table of the Crown Prince and the table opposite the King are removed. Servants enter and sweep (the room) with brooms and leave.

The existence of such written codes of stylised conduct demonstrates the apparent emphasis upon court ceremonial and brings to mind Norbert Elias' study of Louis XIV's court at Versailles. ${ }^{28}$ Elias emphasized the particular nature of the relationship between the French king and his nobles that came to be entrenched in an elaborate system of etiquette and ultimately came to focus upon the granting or refusal

\footnotetext{
${ }^{28}$ Norbert Elias, Die höfische Gesellschaft: Untersuchungen zur Soziologie des Königstums und der höfischen Aristokratie, Soziologische Texte 54 (Neuwied; Berlin 1969).
} 
of prestige tokens. The system was allegedly successful in manipulating the aristocratic ambitions of the courtiers and their fixation upon honour and distinction to a point where the court became a royal venue for reducing the political power of the nobles. However, in reaction to infrastructural problems the Assyrian rulers did in fact delegate considerable political and executive power to their magnates and governors, ${ }^{29}$ and the text instead seems to point to another characteristic feature of all royal courts, namely the prominence placed on the physical re-enactment of the hierarchical structures constituting its social fabric. A more explicit example of this pattern is seen in the following excerpt from the Assyrian ritual of coronation:

After they have presented the audience gifts to the king, the grand vizier and the deputy vizier lay down their sceptres before the king, the... his money bag, the chief singer his lyre, and each of the governors the (emblem) he is holding. They leave their position, retreat, and stand (waiting). The king then announces: "Each of you keeps his office". They prostrate themselves and grovel, draw near (again) and take up their position (again). ${ }^{30}$

The constituent elements in such formalised systems of behaviour are often tied directly to a particular setting for their physical performance-a ballroom, a throne-suite, an office, a sacred place and so forth. Hierarchical divisions are made tangible through the appropriation of space, and both horizontal order (masses in lines, marching soldiers or the relative positioning of individuals) and vertical separation (balconies, thrones, terraces, 'windows of appearance') play a vital role in maintaining and emphasizing existing social order on a symbolic level. Strict protocol and court etiquette underline the boundaries of the physical space in a stylised fashion to promote or emphasize collective consciousness and relative social standing.

Hundreds of administrative records, lists and inventories add a great deal of information to the picture of life at court and the size and makeup of the imperial household. Accounts deriving from the royal wine cellars record the daily allotments of wine distributed among palace staff allowing us to offer a fairly accurate estimate that as many as

${ }^{29}$ For a critique of Elias and his followers, who construe the court of the Sun King almost as a gilded prison for powerless magnates, see the introduction to Jeroen Duindam, Vienna and Versailles: The Courts of Europe's Dynastic Rivals, 1550-1780, New Studies in European History (Cambridge 2003), as well as his contribution in the present volume.

${ }^{30}$ KAR 216+135+137 iii 7-14, edited in Müller, Das assyrische Ritual, pp. 47-49. 
6,000 people were affiliated with the royal court-or rather, the royal institutions-at Nimrud in the 8th century B.C. ${ }^{31}$ This figure, which dates to a period when the Assyrian Empire was subjected to internal crisis and decentralization, may appear improbable at first glance, but, when compared to the claims of Dinon and Ctecias that some 15,000 people were provided for each day at the Persian court, the number of staff seems less astounding. ${ }^{32}$

According to the Greek accounts only the most important visitors to the Persian court were seated near the king's table, and the remaining nobles, the army and foreign dignitaries would be served in the palace courtyard. At banquets in the North-West Palace at Nimrud the principal visitors and officials could have been entertained in the suite of reception rooms west of the inner courtyard, while less important officials may have been seated on the terrace, west of the suite overlooking the Tigris, or in the inner courtyard where postholes for the support of tents or sun sails have been uncovered by the excavators. At the truly great gatherings even the palaces would not have been sufficient to entertain all the invited guests, and on such occasions we must suppose that the great courtyards, the royal parks or some other large spaces were engaged for the purpose.

The so-called 'Banquet Stela' set up to commemorate the inauguration of the new state capital and the North-West Palace at Nimrud gives us some important clues to the demography of the royal city and the size of the extended royal household:

When Assurnasirpal, king of Assyria, consecrated the Joyful Palace, the Palace Full of Wisdom, in Calah, (and) invited inside Assur, the great lord, and the gods of the entire land; 100 fat oxen, 1000 calves (and) sheep of the stable, 14,000...-sheep which belonged to the goddess Istar my

${ }^{31}$ Wilson, Nimrud Wine Lists, with a critical review of the figures provided in Frederico Mario Fales, 'A Fresh Look at the Nimrud Wine Lists', in: Drinking in Ancient Societies, Lucio Milano, ed., History of the Ancient Near East Studies 6 (Padova 1994) pp. 361-380.

${ }^{32}$ Athenaeus XII.538c. A single set of records (Fales and Postgate, Imperial Administrative Records, nos. 21-22) appears to summarize the total number of personnel related to the households of various Assyrian officials and institutions in a rather unclear context: (beginning destroyed) [x hundred, the b]odyguards; [x hundred, the horse train]ers of the open chariotry; [ $x$ hundred, the p]refects of the royal corral; $[x$ hundred, the ch]ariot fighters; 300, the mule house men; 520, the high officials; 300, the domestics; 300, the tailor; 220, the cupbearer; 400, the cooks; 400, the confectioners; 200, the scribes; 1,200, the Lady of the House; 800, the chief eunuch, [x hundred, A]hu-duri; [x hundred, De]nu-amur (rest destroyed). 
mistress, 200 oxen which belonged to the goddess Ištar my mistress, 1,000 siserhu-sheep, 1,000 spring lambs, 500 aiialu-deer, 500 deer, 1,000 large ducks, 500 ducks, 500 geese, 1,000 mesukku-birds, 1,000 qāribu-birds, 10,000 pigeons, 10,000 turtle doves...

The list continues for about half a page more, concluding with the passage:

When I consecrated the palace of Calah, 47,074 men (and) women who were invited from every part of my land, 5,000 dignitaries and envoys of the people of the lands of...16,000 people of Calah, (and) 1,500 zariqui [officials] of my palace, all of them-altogether 69,574 (including) those summoned from all lands and the people of Calah-for ten days I gave them food, I gave them drink, I had them bathed, I had them anointed. (Thus) did I honour them (and) send them back to their lands in peace and joy. ${ }^{33}$

The presence of some 16,000 guests resident in the new city leads to the assumption that a large part of the population of the city were somehow affiliated with the palace or the religious institutions on the acropolis in various functions. The comparable figure of 1,500 officials employed at the palace may then represent the officials directly associated with the royal household, and the total seems roughly comparable to that given by Dinon and Ctecias. The volume of food and drink consumed at the feast may also be compared to the record found in Polyaenus' collection of Strategems (IV.3.32) about the ingestion of the Persian court. He states that some 2,000 ardabs of flour, 400 sheep and billy goats, 300 lambs, 100 cows, 30 horses, 500 geese, 900 assorted birds, 30 gazelles, and tons of milk, garlic, onions, spices, fruit, jellies, oil, nuts and almonds were consumed each day. ${ }^{34}$

Polyaenus draws up this list only to offer his moral conclusions about the detrimental effects of an excessive diet, yet the account, if it is to be trusted, is indicative of the huge number of palace clients associated with the Persian court before the arrival of Alexander and his army. In the case of Assyria we know that also the queen, the crown prince and the magnates maintained separate households of a substantial size in the state capital. Administrative records contain references to the

\footnotetext{
${ }^{33}$ Grayson, Assyrian Rulers, A.0.101.30, pp. 102-154.

34 The full list is given in Briant, From Cyrus to Alexander, pp. 286-287. The text by Polyaenus opens with the following statement: "Since Alexander was in the Persian royal residence, the Great King's lunch and dinner were served to him according to what was inscribed on a bronze pillar, which also bore the other rules instituted by Cyrus. Here is what they contained."
} 
eunuchs, guards, charioteers, transporters, standard-bearers, scribes, craftsmen, overseers, doctors, diviners, musicians, kitchen staff, stable attendants, interpreters etc. active in the royal cities. Lists of court personnel are also quite common, providing us with evidence for some of the different groups present at the Assyrian court at a given time. One example contains a record of some 200 individuals associated with the royal palace that includes prefects, bodyguards, confectioners, chariot drivers, priests, boatmen, couriers, wine-managers, butchers, horsetrainers, trackers, guards and shepherds, to name but a few..$^{35}$ Occasionally we find lists of professionals hired for special tasks, such as architects, doctors, scribes, ironsmiths, diviners and potters, and in a similar fashion, records assign lodgings to officials who were clearly quartered outside the building in 'the residences beneath the window' or in the 'premises of the chief eunuch', 'the magnates', 'the brewers', 'the scribes' or 'the governor'. ${ }^{36}$

The intricate makeup and complex hierarchical structure of this wider 'outer court' and the closely associated imperial army are intermittently revealed in the so-called 'insurrection queries' directed by the royal extispicists to the divinatory Mesopotamian sun deity:

Šamaš, great lord, give me a firm, a positive answer to what I am asking you!... Will any of the eunuchs or the bearded officials-the kings' entourage-or any of his brothers and uncles, his family, his father's line, or junior members of the royal line, or the 'third men', chariot drivers or chariot fighters, or the recruitment officers, or the prefects of the exempt military, or the prefects of the cavalry, or the royal bodyguard, or his personal guard, or the keepers of the betannu gates, or the keepers of the outer (qannu) gates, or the 'rakku' eunuchs, or the [...] or the palace supervisors, the staff-bearers, the watchmen, the mounted scouts or the trackers, or the lackeys, tailors, cup-bearers, cooks and confectioners, the entire body of craftsmen, or the Itu'ean (auxiliaries), or the Elamite, the mounted archers, the Hittites or the Gurreans or the Arameans, the Cimmerians or the Philistines, or the Nubians, the Egyptians or the Šabuqeans, or the armed eunuchs, or the bearded officials who bear arms and stand guard for the king... will any man make an uprising and rebellion against Assurbanipal, son of Esarhaddon, king of Assyria? ${ }^{37}$

${ }^{35}$ Fales and Postgate, Imperial Administrative Records, no. 5.

${ }^{36}$ Fales and Postgate, Imperial Administrative Records, nos. 8-12.

37 Ivan Starr, Queries to the Sungod. Divination and Politics in Sargonid Assyria, SAA 4 (Helsinki 1990) no. 142. 
No great kitchen has been found in relation to the North-West Palace, and the abundance of meat, fish, sweets, fruit, wine, beer, spices, and vegetables recorded by palace officials would have been prepared elsewhere. Similarly, records show that the Assyrian palaces resounded with song and music of various ensembles sponsored by the courts of the king, the queen and the magnates who must have resided beyond the palace walls. Clearly, the extended or 'outer' court included much more than just the royal palace and the auxiliary buildings found on the citadel mound at Nimrud, and it seems reasonable to assume that a considerable fraction of those active at the palace were in fact free agents and artisans in the occasional employment of the royal court. A letter dated to the reign of Sargon II hints at the large amounts of ready cash available in Assyrian society by reference to a number of substantial loans taken by the king from independent merchants to help finance the grand building programme associated with the moving of the state capital to the site of Khorsabad. ${ }^{38}$

\section{The 'Women's Quarters'}

The private section of the Assyrian palaces is commonly referred to in the scholarly literature as the royal 'harem'. A number of enduring stereotypes based upon prejudiced accounts of the Persian, Ottoman and Chinese courts as golden cages of deprivation or hotbeds of conspiracy have been systematically dismantled in recent years as part of the general Orientalism debate. ${ }^{39}$ The continued use of the term to denote the

${ }^{38}$ Simo Parpola, The Correspondence of Sargon II, Part I. Letters from Assyria and the West, SAA 1 (Helsinki 1987) no. 159. The loan provided by the merchant Šulmanu-[...] to the Assyrian king, which is specifically referred to in the letter, amounts to the remarkable sum of 570 minas (c. $280 \mathrm{~kg}$ ) of silver. See Mikko Luukko and Greta van Buylaere, The Political Correspondence of Esarhaddon, SAA 16 (Helsinki 2002) no. 54 for an additional example of the Assyrian king raising cash through loans from private merchants.

39 See e.g. Stephanie Dalley and Nicholas J. Postgate, The Tablets from Fort Shalmaneser, Cuneiform Texts from Nimrud 3 (London 1984); Joan G. Westenholz, 'Towards a New Conceptualization of the Female Role in Mesopotamian Society', Journal of the American Oriental Society 110, 3 (1990) pp. 510-521; Karen Radner, Die Neuassyrischen Privatrechtsurkunden als Quelle für Mensch und Umwelt, State Archives of Assyria Studies 6 (Helsinki 1997); Sarah Melville, The Role of Naqia / Zakutu in Sargonid Politics, State Archives of Assyria Studies 9 (Helsinki 1999); Marc Van de Mieroop, Cuneiform Texts and the Writing of History (London; New York 1999); Zainab Bahrani, Women of Babylon, Gender and Representation in Mesopotamia (London; New York 2001); Elna K. Solvang, A Woman's Place is in the House: 
private section of a palace where the women were typically quartered must therefore be qualified to disassociate it from the simplistic view that the women associated with the palace were invariably present for sexual purposes and forced to live under miserable conditions. As shown below, some of the royal women do indeed seem to have led prescribed lives, yet others just as clearly held powerful positions at the imperial court with wealth and agency in their own right.

A term with connotations similar to the 'harem' was used in Assyrian to refer to the social institution linked to the private sector of palace, namely the bèt issäte or the 'House of the Women'. Although the general term for the private wing of the palace appears to have been the bitānu or 'Inner Quarters', ${ }^{40}$ there existed this distinct unit within its walls, which must have included the residence for the royal women

Royal Women of Judah and Their Involvement in the House of David, Journal for the Study of Old Testament Supplement Series 349 (London; New York 2003); Saana Teppo, Women and their Agency in the Neo-Assyrian Empire, unpub. MA thesis, University of Helsinki (Helsinki 2005) Saana Teppo, 'The Role and the Duties of the Neo-Assyrian ŠAKINTU in the Light of Archival Evidence' State Archives of Assyria Bulletin 16 (2007) pp. 257-272 and the critical discussions in Julia M. Asher-Greve, 'Feminist Research and Ancient Mesopotamia: Problems and Prospects', in: A Feminist Companion to Reading the Bible, Athalya Brenner and Carol Fontaine, eds. (Sheffield 1997) pp. 218-237, and Elna K. Solvang, 'Another Look 'Inside': Harems and the Interpretation of Women', in: Orientalism, Assyriology and the Bible, Steven Holloway, ed. (Sheffield 2007) pp. 374-398. In general, the conception of the 'oriental harem' can be shown to derive from 19th-century representations of Oriental decadence, which ultimately date back to a Greco-Roman ideological discourse through the intimate intellectual bond between classical tradition and the late romanticist movement. One finds such legendary accounts as the story of Sardanapalus, "who lived in recluse in his palace, seen only by his eunuchs and wives", himself an "effeminate debauchee, sunk in luxury and sloth." - notes by E. H. Coleridge from Works / Lord Byron, 18981904, "Sardanapalus" by George Gordon, Lord Byron. The same image repeated in the poems and literary works by Choerilus, Ctesias and Dickens and in paintings e.g. by Delacroix (La Mort de Sardanapale. 1827-28. Oil on canvas. Louvre). Note e.g Charles Dickens: A Tale of Two Cities, II: XXIV: "It had never been a good eye to see with-had long had the mote in it of Lucifer's pride, Sardanapalus's luxury, and a mole's blindness".

${ }^{40}$ Note also the term 'Second House' (bètu šaniu), which may in some instances refer to the servant quarters of a royal palace, though it could also represent a separate building used to house the palace staff (for discussions, see Radner, Die Neuassyrischen Privatrechtsurkunden, p. 272, and Ahmad and Postgate, Archives, p. 6.) Note also Samuel M. Paley and Richard P. Sobolweski, The Reconstruction of the Relief Representations and their Positions in the North-West Palace at Kalhu (Nimrüd) III, Baghdader Forschungen 14 (Mainz 1992) p. 47, and Russel, 'The Program of the Palace of Assurnasirpal II at Nimrud', pp. 666-667, who on the basis on an inscribed slab discovered in secondary archaeological context suggest that the 'Second House' may have been the state apartment located west of the throne room and facing the Tigris. A 'First House' would have referred to the throne-room suite itself, and the 'Second 
and children. The recent discovery of the rich tombs of the Assyrian palace ladies ( $\check{a} a$ ekalli) in the southernmost wing of the North-West Palace corroborates the notion that the rear section of the building would have served as the private quarters of the royal family, and that its narrow rooms and halls were home to the eunuchs and ladies belonging to the king's household. Unfortunately, our understanding of the Assyrian bèt issāte and bitānu remains fairly vague.

The social institution of a 'harem' as such has a long history in Mesopotamia and goes back at least as far as the time of the Ur III Empire (2112-2004 B.C.). It is well documented in the palace archives from the state of Mari on the Euphrates (c. 1775 B.C.), and typified in the written reproach by the aging King Shamshi-Addu to his son and viceroy for preferring to lie in the arms of his concubines instead of taking care of business. It seems clear however, that the Assyrian 'harem' was rather different from the ones found in later Istanbul or Beijing both in size and character. Admittedly our main source for the Assyrian institution of the 'harem' comes from a collection of palace decrees (riksu) dated to the 11th century B.C. that pre-dates the NeoAssyrian imperial expansion, but a number of the points evidenced in the edicts may well have applied also to its later manifestation at the North-West Palace.

The documents in question are poorly preserved, and of 23 individual stipulations no more than half can be interpreted with any certainty. ${ }^{41}$ However, in spite of their fragmentary nature, the decrees give a view of what life must have been like in the Women's Quarters. The old royal palace in Assur that served as a precursor to the North-West

House' would in that case have been the 'Banquet House' of the palace (Russel, 'The Program of the Palace of Assurnasirpal II at Nimrud').

${ }_{41}$ The Middle Assyrian Palace Decrees (also referred to as the 'Harem Edicts') represents a collection of regulations dealing with the internal activities of the palace personnel. The collection as we have it was assembled in the time of Tiglath-Pileser I (1114-1076 B.C.) and includes decrees issued by nine kings. Eight of the tablets (now in Berlin) were published by Ernst Weidner, 'Hof- und Harems-Erlasse assyrischer Könige aus dem 2. Jahrtausend v. Chr.', Archiv für Orientforschung 24 (1954-56) pp. 122-127. A ninth (at Yale) without documented provenience was published in Gary Beckman, and Benjamin Foster, 'Assyrian Scholarly Texts in the Yale Babylonian Collection', A Scientific Humanist. Studies in Memory of Abraham Sachs, in Erle Leichty et al., eds. (Philadelphia 1988) pp. 1-26. An edict from 14th century Nuzi, i.e. roughly contemporary with the earliest of the Assyrian Palace Decrees, dictates the internal code of behaviour in regard to the alienation of female palace slaves and palace retainers. 
Palace in Nimrud was a crowded place, and by the time the edicts were composed the building had stood for centuries. ${ }^{42}$ The small edifice with narrow corridors and dark courtyards served a wide variety of functions that clearly made it difficult to separate people properly. Groups that were not supposed to have any contact would occasionally run into each other, and a number of edicts are concerned explicitly with correct behaviour under such circumstances. We hear about the required conduct of visiting midwives, and one paragraph deals with the impurity of menstruating women. Finally, a series of stipulations are concerned with the corporal punishments that a palace woman was sanctioned to perform upon her female servant, but also the penalties if her servant should accidentally die from the harsh treatment.

It is difficult to estimate the number of women living in the Old Palace in Assur, but it seems that only a limited number would have had permanent residence in the building. In addition to the queen and the king's mother, the palace housed a certain number of secondary wives and other 'palace women' (sekretu), ${ }^{43}$ and servant girls assigned to each of these women would have resided in the palace part-time. Some such servants were apparently married to men who lived outside in the city, since one of the edicts is concerned with the regulations for their leaving the building on their days off. In spite of all this, the Middle Assyrian decrees do in fact give the overall impression that the 'harem' of the Old Palace was a physically restricted space in which the royal women were kept in loneliness and boredom: ${ }^{44}$

If a woman of the palace has bared her shoulders and is not covered with even a loincloth, and she summons a court attendant, [saying:... "come hither"]- "I wish to give you an order", and he tarries to speak with herhe shall be struck by 100 blows. The eyewitness who denounces him shall

${ }^{42}$ For the Old Palace in Assur, see Friedhelm Pedde and Steven Lundström, Der Alte Palast in Assur. Architektur und Baugeschichte, Wissenschaftliche Veröffentlichungen der Deutschen Orient-Gesellschaft 120 (Wiesbaden 2008), and Jan Gerrit Dercksen, Old Assyrian Institutions, Publications de l'Institut historique- archéologique néerlandais de Stanboul 98 (MOS Studies 4) (Leiden 2004) pp. 7-9 with further references.

${ }^{43}$ For the sekretu, literally 'sequestered woman', cf. Sarah Melville, 'Neo-Assyrian Royal Women and Male Identity: Status as a Social Tool', Journal of the American Oriental Society 124 (2004) p. 40, and Teppo The Role and the Duties, p. 265.

${ }^{44}$ For a thorough evaluation of the conditions in the 'harem' of the Old Palace in Assur, see Solvang, 'A Woman's Place', and eadem, 'Another Look 'Inside'. 
take his clothing; and as for him, they shall tie (only) sackcloth around his waist. ${ }^{45}$

It also transpires that a palace woman was expected to remain 'veiled for her master' at all times, and that cruel punishments threatened a lady if she allowed even her female servants to see her uncovered face. Officials were forbidden to eavesdrop on them, and were whipped if they were caught overhearing them quarrelling or singing. Little freedom was provided to move within the palace for those few who were allowed entry, and palace staff was to maintain a distance of seven paces when talking to a lady. Even when a eunuch was sent to the 'harem' on an errand by the king he could only enter after informing the palace manager ( $r a b$ ekalli), who was to stand guard at the entrance while the official went in and out.

When the entire royal court journeyed to another city, the palace staff presumably had an opportunity to experience the world outside the walls. There is nothing to indicate that such travels were as common as in the later Persian Empire, but clearly the court did occasionally move from one palace to another. In Neo-Assyrian times several courts with separate households and 'harems' were present in the capital cities, and we may presume that an exchange of residents and staff took place between them. When the king chose to spend a longer period outside his residential palaces, a large part of the court would presumably have moved with him. Our only direct evidence for travelling courts once again dates back to the Middle Assyrian period and comes from the correspondence of a 13th-century governor in the regional capital of Dur-Katlimmu. A letter from his archive announces the imminent arrival of the Assyrian king to the provincial palace, and concerns itself with the minutiae associated with the coming of prominent visitors:

The court will be large. The lady Qa'i-mätu and two more ladies are in charge of the thirteen women-both our own ladies and the Kassite ones. Two female stewards, and similarly, one female šatalšuttu, in all six carriages arriving from the king... the Kassite king and his wife will arrive together with the king. ${ }^{46}$

${ }^{45}$ Most recently translated and edited in Martha T. Roth, Law Collections from Mesopotamia and Asia Minor (Second Edition), Writings from the Ancient World Society of Biblical Literature 6 (Atlanta 1997).

${ }^{46}$ E. Cancik-Kirschbaum, Die mittelassyrischen Briefe aus Tall Šêh Hamad, Berichte der Ausgrabung Tall Šēh Ḥamad/Dūr-Katlimmu 4 (Berlin 1996) no. 10. 
On the basis of this information, it would seem that the 'harem' was made up of no more than thirteen women, including the wives of the Kassite (Babylonian) king who was held captive at the Assyrian court at the time. All were under the charge of a lady named $Q a^{\prime} i-m a \bar{t} u$ assisted by five additional women. If we assume that the entire court was on the move as indicated by the additional presence of the Babylonian king, the size of the Assyrian 'harem' in the 13th century B.C. appears to have been of fairly limited proportions.

The Neo-Assyrian evidence for the 'harem' is less clear, although a few facts do emerge. Clearly, social monogamy was the norm and the king was married to one wife only. ${ }^{47}$ This first lady was regarded as the queen of the empire: she was the head of her own separate household, and as a rule she was the mother of the designated heir to the throne. As indicated also by the ground plan of the North-West Palace, she presumably occupied a palatial suite physically separate from the rest of the bitannu. However, the extended female retinue of the Assyrian king appears to have been much larger than in Middle Assyrian times, and a substantial number of 'Palace Women' (sekretu), adolescent children and servants seem to have resided in the 'House of the Women'. Relatively little is known about the life of these sekretus. Mostly they appear in lists of wine-rations and records of booty taken by the Assyrian kings, and often they are associated with the stock phrase 'beloved by the king'. The word is itself derived from the verb sekeeru, meaning 'to close, to confine, to hold in, to block or restrain', suggesting that they were generally associated with life in isolation. However, the sekretus are occasionally noted as the buyers of slaves and real estate, proving that their agency reached beyond the palace walls.

The 'Palace Women' of the Assyrian palaces are known to have originated from all over the ancient world, and local nobles, client kings and foreign rulers would send daughters to the court for political and social reasons. Similarly, incorporating the households of defeated enemies was common practice, and scattered records mention Aramean, Kassite, Hittite and Nubian women as well as ladies coming from Namri, Tyre, Arpad, Ashdod, Jerusalem, Memphis and

${ }^{47}$ But note the discussion in Julian E. Reade, 'Was Sennacherib a Feminist?', in: La Femme dans le Proche-Orient Antique: XXXIIIe Rencontre Assyriologique Internationale, Jean-Marie Durand, ed. (Paris 1987) pp. 139-145. 
Dor at the Assyrian palaces. One list appears to record all the female occupants of 'the women's quarters' in an Assyrian palace, and almost a hundred women and fifty servants (amat ekalli) appear on the list with the addition of 61 female musicians, singers and an inventory of other female personnel, including scribes, smiths, stone-borers, a hairdresser and a perfume-maker for a grand total of some 250 individuals. ${ }^{48}$ A significant part of this female staff would doubtless have resided outside the royal palace itself as indicated by the occasional reference to a "house of the palace maids". ${ }^{49}$ And surely not all the women were segregated from the male part of the population, as one record mentions the 370 sons of the slaves and the palace maids. ${ }^{50}$ Such 'sons of the palace maids' generally appear in contexts suggesting that they held a strong financial position and that they could lend out money and receive estates as royal gifts.

Administrative records found in the bitannu-wing of North-West Palace also reveal the presence of some of the male officials associ-

${ }^{48}$ Fales and Postgate, Imperial Administrative Records, no. 24; other lists of female personnel are at no. 23 and nos. 25-26. Noting the reservations found in Fales, 'A Fresh Look at the Nimrud Wine Lists', pp. 361-380 and Teppo, The Role and the Duties, p. 267, this figure fits well with the 250 members of the queen's household as calculated by Wilson, Nimrud Wine Lists, on the basis of the Nimrud wine-lists. Similar numbers are reached by Teppo for Nineveh in the early 7 th century on the basis of the amounts of flax distributed to the palace. According to her calculations, the provincial palaces in Arbail, Kilizi, Adian and Kasappa held between 70 and 164 palace women each. If the households run by the šakintus were all under the queen's administration, she would thus have been the head of hundreds of people based not only in the royal palace but spread across her holdings throughout the empire. See Melville, Role of Naqia, pp. 105-112, Teppo, Women and their Agency, and Teppo, The Role and the Duties for the relevant data on the šakintu households and the reasons for abandoning the old translation of the title as 'harem governess'. The office of the šakintu was not exclusive to the royal palace, and apparently all large households in Assyria could or would have a woman's section headed by a 'Lady of the House' (bēlat bèti) assisted by a šakintu. See e.g. the list of šakintus in Fales and Postgate, Imperial Administrative Records, no. 23, the letter in Luukko and Buylaere, Political Correspondence, no. 28 quoted below, and the lists in Fales and Postgate, Imperial Administrative Records, nos. 21-22 that appear to record almost 1,200 individuals belonging to the personnel of one particular bèlat bèti.

49 Text ND 2307, see Teppo op. cit.

${ }^{50}$ See Parpola, Correspondence of Sargon II, no. 99. A badly preserved marriage contract between a man named Atar-[...] and a woman of some apparent status, perhaps a former palace maid, was unearthed in one of the rooms (DD) in the bitannuwing of the North-West Palace. Postgate, The Governor's Palace Archive, no. 247. Among the preserved stipulations we are informed that the man is prohibited from taking a second wife, and that the lady he now marries will be excluded from any financial responsibility for her husband's eventual debts. 
ated with the private activities of the palace household and offer a glimpse of the activities going on in the 'harem'. There is evidence to show that weaving and textile production were a part of daily life, and that the study and performance of poetry and music would have been favoured pastimes. The cold building and the rich food and drink consumed in the 'women's quarters' seem to have taken their toll on the residents. ${ }^{51}$ Paleopathological examinations of the skeletons from the palace tombs show that common ailments were malnutrition (caused by excess) and rheumatism. ${ }^{52}$ Epidemic outbreaks would surely have spread fast in the confines of the private quarters, and the fact that several royal women were buried at one time and in a single grave might indicate that their deaths happened too fast and too close in time to observe the proper rites. ${ }^{53}$ One short sad poem, seemingly composed by a lady of the palace, recalls the despair associated with the loss of a stillborn child, ${ }^{54}$ and an exceptional manuscript recounts the rites performed at the burial of a palace lady by her fellow women. ${ }^{55}$ Finally, one finds occasional evidence for social tension among the residents of the royal palaces:

Word of the king's daughter to Libbali-šarrat. Why don't you write your tablet and do your homework? For if you don't, they will say: "Is this the sister of Šerua-eterat, the eldest daughter of the Succession Palace of Aššur-etel-ilani-mukinni, the great king, mighty king, king of the world,

${ }^{51}$ For various lists of food, drink and aromatics consumed at the palace banquets and the queen's court, see Fales and Postgate, Imperial Administrative Records, nos. 130-157.

${ }_{52}$ M. Schultz and M. Kutner, 'Erste Ergebnisse der anthropologischen und paläopathologischen Untersuchungen an den menschlichen Skeletfunden aus den neuassyrischen Königinnengräbern von Nimrud', Jahrbuch des Römisch-Germanischen Zentralmuseums Mainz 45 (1998) pp. 85-128, and Oates, Nimrud, pp. $87 \mathrm{ff}$. Six of seven adults examined showed signs of degenerative joint disease, and only the "child queen" of tomb III had healthy joints. Out of eight skeletons, four adults and one child bore indications of deficiency or persistent disease during infancy. It would also seem that the women of the palace ate extremely soft foods, suffered severely from colds, and were unaccustomed to exercise.

${ }_{53}$ The present explanation for the shared burial of the individuals is far from certain, and may have been caused by secondary deposit as well. Cf. Oates, Nimrud, p. 87, who suggests that the secondary interments may have been caused by power struggles among the leading families from which the women came.

${ }_{54}$ Alasdair Livingstone, Court Poetry and Literary Miscellanea, SAA 3 (Helsinki 1989) p. 15.

${ }^{55} \mathrm{~K} 164$. Wolfram von Soden, 'Aus einem Ersatzopferritual für den assyrischen Hof', Zeitschrift für Assyriologie und Vorderasiatische Archäologie 45 (1939) pp. 42-61, Taf. VII, on no. 45: "Die Palastfrauen (lit. MÍ É.GAL.MEŠ: 'queens') rufe[n:] "Kommt! Die Palastfrau, eure Tochter, [sollt ihr] begraben". 
king of Assyria?" Yet you are only a daughter-in-law-the lady of the house of Assurbanipal, the great crown prince designate of Esarhaddon, king of Assyria. ${ }^{56}$

The head administrator of the queen's household bore the title šakintu..$^{57}$ Her staff seems to have been almost exclusively female and included her deputy, stewardesses, scribes, a treasurer and several cup-bearers. The šakintus show up regularly in the texts, and actually represent the best-attested group of women within the Assyrian palaces. So far, some 54 šakintus in 22 separate households are known from the records, and clearly their position was both an influential and an economically rewarding one. A major task seems to have been the organisation of the substantial textile production that took place inside the palaces, but šakintus are also seen to buy slaves, lend money, control large amounts of provisions, and act in various types of legal transactions. Most such dealings were presumably connected to her professional duties, but some documents imply that the ladies held similar autonomy in their private lives, and that the šakintus could have or adopt children. In one case we know that a former 'Palace Woman' (sekretu) held the office of šakintu, opening the possibility that this may have been a regular career opportunity for ladies living in the palaces.$^{58}$ Obviously, they would be uniquely placed to seek this kind of promotion and to carry out the tasks involved in the job. We know of a number of sakintus distributed among the palaces of the Empire, and it seems likely that each palace had a female manager working side by side with the male staff so that the šakintu held a position comparable to the palace supervisor. ${ }^{59}$ The association between her office and the royal 'harem' is less clear, and it is difficult to determine exactly

\footnotetext{
${ }^{56}$ Luukko and Buylaere, Political Correspondence, no. 28.

${ }^{57}$ Cf. Teppo, The Role and the Duties, for a comprehensive study of the Assyrian šakintu.

${ }^{58}$ Ahi-talli, administrator of the Central City in Nineveh during the reign of Sennacherib (after 686 B.C.). She is known from several documents, buying slaves, and once a girl from her mother. Again, see Teppo, Women and their Agency, pp. 56-57.

${ }^{59}$ It is tempting to associate the small room just south of what seems to be a hall giving direct access into the bètānu at the protruding east corner of the North-West palace with the office of the šakintu. When excavated, the room contained both the traces of a rich female occupant, and a small archive of administrative dockets relating to the procurement and distribution of animals and commodities such as camels, sheep, wool and copper. For the finds in the room (HH), see Oates, Nimrud, p. 62. The dockets are published in Postgate, Governor's Palace Archive, nos. 250-263.
} 
what sort of connection existed between the 'women's quarters' and the court of the queen.

\section{The Royal Eunuchs}

A final principal component of the Assyrian royal household was made up of a substantial corps of officials referred to as 'the king's $\check{s} a$ rēši. Generally the title has been taken to refer to male eunuchs engaged by the palace, yet the matter of the existence and the number of eunuchs in the Neo-Assyrian royal household has been the subject of some controversy in recent years. The apparent omnipresence of the $\check{s} a$ réši-officials at court led the French assyriologist Paul Garelli to doubt whether the title referred to actual emasculated males. Rhetorically, he posed the question whether it would be "necessary to castrate half of the Assyrian administration and nearly everyone at court". ${ }^{60}$ As an alternative Garelli suggested that the term had simply become a general reference to denote any type of official active at the king's court. More recently Pierre Briant adopted this view in his study of the Achaemenid Empire, and concluded that:

It seems doubtful that eunuchs in the functional sense (castrated men of humble status) have obtained positions as high as the eunuchs mentioned by Ctesias... [rather, it was] a title completely unrelated to the duty it literally represented, as is often true in court hierarchy. ${ }^{61}$

This reluctance to accept the existence of high-positioned eunuchs at the Assyrian and Achaemenid court seems unwarranted. It is based mostly upon an apparent prevalence of eunuchs, even among the highest officials of the empire, and the disbelief that castrated men in

${ }^{60}$ P. Garelli, 'Remarques sur l'administration de l'empire Assyrien', Revue d'Assyriologie et d'archéologie orientale 68 (1974) pp. 129-40, and Reallexikon der Assyriologie [RlA] 4, pp. 449-450. For similar views, see also A. Leo Oppenheim, 'A Note on ša rēši', The Journal of Ancient Near Eastern Society of Columbia University 5 (1973) pp. 325-334; Wolfram von Soden, Akkadisches Handwörterbuch (Wiesbaden 1958-1981) p. 974; John A. Brinkman and Stephanie Dalley, 'A Royal Kudurru from the Reign of Aššur-nadin-šumi', Zeitschrift für Assyriologie und Vorderasiatische Archäologie 78 (1988) pp. 85-86 n. 27, and most recently, Stephanie Dalley, 'Evolution of Gender in Mesopotamian Mythology and Iconography with a Possible Explanation of ša rešen, "the man with two heads", in: Proceedings of the 47th Rencontre Assyriologique Internationale, Helsinki, July 2-6, 2001, S. Parpola and R. M. Whiting eds. (Helsinki 2002) pp. 117-122, with further references.

${ }^{61}$ Briant, From Cyrus to Alexander, p. 276. 
large numbers would obligingly function in positions of political and executive power. Substantial evidence has recently been presented in support of the notion that the Assyrian $\check{s} a$ rēš were in fact castrates adopted into a palatial household and directly tied to their master in a manner comparable to kinship. ${ }^{62}$ The male officials at the NeoAssyrian palaces were commonly divided into two functional groups, the 'bearded courtiers' (ša ziqni) and the $\check{s} a$ rēši, and a clear distinction was drawn between the former, who were understood to produce 'sons', and the latter who had only 'successors'. Upon entering royal service, the ša resši would give up his former filiation $\left(\mathrm{NN}_{1}\right.$ son of $\mathrm{NN}_{2}$ ) and receive a new name that would often include a reference to the distinct nature of his commitment to the ruler. General Assyrian belief held that a person's well-being in afterlife depended upon regular funerary offerings provided by his or her descendants, and since the $\check{s} a$ rēši lacked the capability to procreate, they could either adopt children, or the king might personally commit himself to provide for his servants in afterlife. The latter practice resulted in a number of standardized royal grants recording the creation of tax-exempt foundations to serve the $\check{s} a$ rēši.$^{63}$

The Middle Assyrian edicts include stipulations concerned with the actual procedure for checking whether court personnel (manzaz pāni) had been properly castrated before being allowed to enter the women's

${ }^{62}$ Albert K. Grayson, 'Eunuchs in Power: Their Role in the Assyrian Bureaucracy', in: Vom Alten Orient zum Alten Testament: Festschrift für Wolfram Freiherrn von Soden zum 85. Geburtstag am 19. Juni 1993, Manfried Dietrich and Oswald Loretz, eds. (Freudenstadt 1995) pp. 85-98; Radner, Die Neuassyrischen Privatrechtsurkunden, pp. 155-157, Karlheinz Deller, 'The Assyrian Eunuchs and Their Predecessors', in: Priests and Officials in the Ancient Near East: Papers of the Second Colloquium on the Ancient Near East-The City and Its Life Held at the Middle Eastern Culture Center in Japan (Mitaka, Tokyo), March 22-24, 1996, Kazuko Watanabe, ed. (Heidelberg 1999) pp. 303-311; Kazuko Watanabe, 'Seals of Neo-Assyrian Officials', in: Priests and Officials in the Ancient Near East: Papers of the Second Colloquium on the Ancient Near East-The City and Its Life Held at the Middle Eastern Culture Center in Japan (Mitaka, Tokyo), March 22-24, 1996, Kazuko Watanabe, ed. (Heidelberg 1999) pp. 313-366; J.D. Hawkins, 'Eunuchs among the Hittites', in: Proceedings of the 47th Rencontre Assyriologique Internationale, Helsinki, July 2-6, 2001, S. Parpola and R.M. Whiting eds. (Helsinki 2002) pp. 217-233, and Tadmor, 'Role of the Chief Eunuch', with further references. For the pictorial evidence, see Julian E. Reade, 'The Neo-Assyrian Court and Army: Evidence from the Sculptures', Iraq. Journal of the British School of Archaeology in Iraq 34 (1972) pp. 87-112, and Watanabe, 'Seals of Neo-Assyrian Officials'.

${ }^{63}$ Cf. Laura Kataja and Robert M. Whiting, Grants, Decrees and Gifts of the NeoAssyrian Period, SAA 12 (Helsinki 1995) pp. xxi-xxxi. 
quarters. The royal servants were subject to regular inspection by a select committee to reveal individuals who had not been properly emasculated, and in case of doubt the unfortunate officials were denied access to the inner quarters and submitted to complementary surgery. It follows that the Assyrians did not employ the practice of complete penectomy - a dangerous procedure that had serious physical and psychological repercussions. Only the testicles were destroyed in the scrotum during adolescence, and presumably the eunuchs would retain their sexual drive and be able to have intercourse.

The 'chief eunuch' ( $r a b \check{s} a$ rešsi) was the nominal head of the imperial eunuchs as well as the commander of the royal corps. ${ }^{64}$ Initially, he may have been the head of the private sector of the royal palace as well, but as the office grew into one of the key positions of power in the empire, it appears that the senior manager of the royal abode came to be the eunuch 'chamberlain' (ša muhhi bètāni-lit. 'the one in charge of the inner quarters'). The male head of the women's quarters may have been the obscure rab issate ('master of the women'). ${ }^{65}$ The archival records discovered in the private wing of the North-West Palace give us very little information about the resident male personnel and the nature of their interaction with its female occupants, but both material and written evidence indicates that palace eunuchs came into direct association with the women's quarters. Plainly, select members of the male staff had direct authority in the upbringing of the royal children, and the quote by Plato stating that it was customary for the Persian heir apparent to be "brought up-not by some nanny of no account, but by the most respected eunuchs in the royal household" has clear parallels in the Assyrian record. ${ }^{66}$

${ }^{64}$ The office of the chief eunuch was subject to significant change in political and military importance from the end of the reign of Shalmaneser III to the downfall of the empire-apparently to the point where the chief eunuch Sin-šumu-lešir took hold of the Assyrian throne during the rebellion of Nabopalassar. If a large proportion of the highest ranking eunuchs at the court were superflous male children born to the royal family, this would of course help to account for their aspirations to kinship. For the changing fortunes of the Assyrian chief eunuchs, see Mattila, King's Magnates, and Hayim Tadmor, 'The Role of the Chief Eunuch and the Place of Eunuchs in the Assyrian Empire', in: Proceedings of the 47th Rencontre Assyriologique Internationale, Helsinki, July 2-6, 2001, S. Parpola and R. M. Whiting eds. (Helsinki 2002) pp. 603-612.

${ }_{65}$ See Radner, Die Neuassyrischen Privatrechtsurkunden, p. 264 and Teppo, Women and their Agency.

${ }^{66}$ Alc. $121 \mathrm{~d}$. Note e.g. the well-known passage in Kataja and Whiting, Grants, Decrees and Gifts, no. 35 and no. 36, in which king Aššur-etel-iläni writes of his childhood that: "Sin-šumu-lešir, the chief eunuch, one who deserved well of my father and begetter, 


\section{Conclusion}

The rapid expansion of the Neo-Assyrian state in the early 9th century B.C. led to the formation of a distinctive imperial ideology and an institutionalised court protocol tied to the dramatic setting created at the North-West Palace in Nimrud. Stylised etiquette and a rigid social hierarchy, combined with strict rules of physical access and an appropriation of space on both an ideological and physical level, acted to sustain an image of a universal empire with the Assyrian king at its central axis. The new capital city celebrated the power of the imperial state and its ruler, and at its nexus stood the throne-room, the large courtyards, the elaborate reception suites and the striking decorations of the royal palace. This was the physical arena in which political and social power was negotiated and dispensed, where loyalties were affirmed, spectacles played out and foreign dignitaries received. It served as the main backdrop for court and elite integration, and functioned as a setting for grand public displays with elaborate dresscodes, musical performances and organised symposia, as well as for more intimate banquets, audiences and ceremonies. Finally, the royal palace was a centre of the imperial bureaucracy and home to the king's family. It housed the royal women, children and eunuchs, and clear physical limits were drawn between the public and the private sectors of the building.

A lot remains to be done before we may reach a detailed understanding of the social and political changes that took place at the Assyrian court throughout its two and a half century long history. Apparent developments in court life can be traced on various levels, both in the constant shifts in the hierarchy of court officials, in the administrative reforms triggered by territorial expansion and internal struggle, and even in the physical layout of the royal palaces. Nevertheless, the North-West Palace and its court remained the basic social and physical template that specifically came to identify the Assyrian imperial style. The Assyrian imperial blueprint drew many of its images and customs from a long-standing palace tradition in the Near East, but its characteristic feature seems to have been the particular combination

who led me constantly like a father, installed me safely on the throne of my father and begetter and made the people of Assyria, great and small, keep watch over my kingship during my minority, and respected my royalty". 
and use of elaborate decoration, ceremony and spectacle assembled in a setting of hitherto unseen proportions. In a sense, the NorthWest Palace became the 'Versailles of the ancient Near East', and the physical structure as well as the associated 'package' of ideas of proper courtly conduct was emulated in all later royal dwellings, as well as in the provincial palaces of imperial magnates and client states. To some degree, one may argue that the later established Persian practice of projecting its claim to world domination through the upkeep of a lavish court had its roots in Nimrud. The North-West Palace was certainly a receptacle of wealth in every manner imaginable: the daughters of allied and subdued rulers lived out their lives there; booty, taxes and tribute were stored in it; the best musicians and artists, the holiest men, the most renowned scholars, and the fiercest soldiers came there to practice their art.

An explanation for the apparent success of this 'image' of the imperial court developed in association with the North-West Palace should perhaps be sought in the fact that, for the incipient empire of Assurnasirpal II in the early 9th century, Assyrian political power remained virtually invisible. Successful military campaigns had little permanence, and the political map of the imperial territories resembled a patchwork rather than a geographic continuum. Important cities and tribal groups in dangerous proximity to the imperial heartland continued to challenge Assyrian supremacy. Instead, the Assyrian empire became fully articulated only through the creation of the new state capital, and the grand inauguration banquet acted to 'bring the empire and its ideology' to the local as well as the foreign dignitaries. In addition to the importance for the Assyrian self-image as a rising empire, the extension and relocation of the royal court from its ancient seat in Assur presumably also helped to establish and codify a new social order among the rapidly expanding political elite, and it acted to disassociate the royal court from the power of the traditional 'old' families dominant in the former capital. The new imperial elite was an inclusive group, and to some degree social status was disassociated from kinship and tied directly to the favour of the king. The North-West Palace would have provided a suitable arena for the games of social positioning, and acted as an appropriate location from which the king could 'divide and rule' his closest subjects. 